\title{
Soviet Agriculture since Khrushchev - Decentralisation and Dirigisme
}

D. A. Dyker

\section{Introduction: from Stalin to Khrushchev}

... The peasantry ... pays a certain supertax in the form of an over-payment for manufactured goods, and in the form of an under-payment received for agricultural produce.... Can we abolish this supertax at the first opportunity, in the next few years ... Unfortunately we cannot. We must abolish it at the first opportunity, in the next few years ... Are we right in calling this additional tax 'something in the nature of a tribute'? Unquestionably we are. By our choice of words we are pointing out to our comrades that this additional tax is detestable and undesirable, and that its continuance for any considerable period is impermissible.

[Stalin 1955:52-4]

Thus Stalin in 1929. When he died a quarter of a century later, the 'tribute' was still being paid. Ironically, contemporary research indicates that the agricultural sector may have made little net contribution to the industrialisation drive in the 1930s [Ellman 1979:92-6]. Such was the destruction of agricultural capital stock, especially livestock, resulting from the harsh imposition of collectivisation on a largely unwilling peasantry that significant counterflows of resources had to be set up to keep agriculture moving at all. What collectivisation did ensure was that there was always a gross flow of food products into the towns adequate to feed the growing urban population. It may also, by destroying the familybased peasant farm, have facilitated the shift of population into the towns (between 1926 and 1939 43.4 million people migrated from rural to urban localities - [Gregory and Stuart 1981:243] though the history of Yugoslavia, for example, suggests that the attraction of rapid industrialisation may be all that is required to generate a population transfer on this scale. Finally, the imposition of direct control over agriculture permitted the Soviet Government to earn precious foreign exchange by increasing agricultural exports. In 193118 per cent of wheat production was exported [Gregory and Stuart 1981:243]. By 1932 the Soviet countryside was in the grip of a famine that cost the lives of millions of peasants.

The immediate cause of [the famine] was not poor harvests but the requisitioning of grain from moderate harvests in such quantities that not enough was left for the peasants themselves. The main reasons for this drastic policy appear to have been, first, the attempt to maintain exports of agriculture produce and hence imports of machinery ...

[Hanson 1968:36]

This may, incidentally, have helped to convince Stalin of the need to allow peasants to farm small private plots which subsequently developed a crucial role, in terms not only of subsistence, but also of supply to the non-farm population of key food items such as eggs. In 195345.7 per cent of aggregate collective farm family income came from the private plots [Ostrovskii 1967:93].

Perhaps the most important 'objective' reason why exaction of the tribute went on so long was the intervention of a disastrous, if ultimately victorious war, which left much of the industrial potential of European Russia in ruins. There is a much better basis for arguing a net transfer of resources from agriculture to industry in relation to the late 1940 s and early 1950 s than for the 1930s, and this may have been a significant factor in the impressive industrial recovery that the Soviet Union made in 1945-55. But in 1954 agricultural output was actually lower than it had been in 1928, and with an ever increasing urban population to feed the policy of putting the priority on procurements rather than production had come to the end of the road.

This was the problem that Khrushchev, who by 1956 had established himself as Stalin's successor, tried to tackle. Khrushchev raised procurement prices sharply, and this permitted peasant incomes to more than double between 1953, the year of Stalin's death, and 1967 [Gregory and Stuart 1981:239]. Just as important, it permitted an upward shift in the flow of investment into the farm sector. (The great bulk of collective farm investment has to be financed by the farm itself.) In 1950 agriculture accounted for 15 per cent of total Soviet gross investment. By 1965 this had risen to 16.7 per cent, though the weight of the sector by output and employment had fallen considerably over that period [Dyker, forthcoming, Chapter 7, Table 7.3]. Better incentives and increased investment facilitated an increase of some 70 per cent in agricultural output from 1954 to 1965 [Gregory and Stuart 1981:249]. But Khrushchev devoted much effort and many resources to various 'campaigns' of 
questionable value. Some, like the maize campaign, were, in the words of his political successors, completely 'harebrained'. Others, like the massive extension of sown area into the semi-arid 'virgin lands', produced impressive short-term results at the cost of long-term environmental damage, as erosion set in. It is perhaps not difficult to see why Khrushchev felt impelled to seek some immediate panacea for a problem at once pressing and embarrassing. But by the early 1960s the long term cost of these adventures were once again pulling down agricultural growth rates. Output from the 'virgin lands' for example, peaked in 1960 and then fell to less than half the 1960 level in the period up to 1963 [Dyker 1976:130].

\section{Developments since 1965 - the Main Features}

The secular policy thrust of the Brezhnev leadership has been essentially a continuation of the Khrushchev approach. Further improvements in agricultural prices permitted the average income of collective farmers from work on the collective farm (kolkhoz) alone to approach 60 per cent of the average for nonagricultural workers by 1975 , with state farm (sovkhoz) income very nearly at the level of non-farm workers by that year [Schroeder and Severin 1976:629]. Taking the private sector into account, the gap between farm and non-farm incomes in the Soviet Union is certainly now no greater than it is in many western countries. Investment inputs into agriculture have also risen steadily throughout the post-1965 period, and agricultural investment as a proportion of total investment was around 20 per cent throughout the 1970s [UN 1977 Part 2:100; 1982:Table 3.2.4.]. The Brezhnev leadership has been less prone to get involved in grand schemes, but the ambitious programme for land improvement in the "non-Black Earth' ie northern region of European Russia, which started in 1974, has been not a little reminiscent of Khrushchevian campaignology. And whatever the precise direction of causation, output and productivity trends over the Brezhnev era have been very similar to those under Khrushchev - an initial sustained spurt, followed by slow-down or stagnation. As Table I shows, Soviet agricultural production was actually lower in 1981 than it had been in 1973. Average annual output of grain showed a modest increase from 181.55 tons in 1971-75 to 205.05 tons in 1976-80 [UN 1982 Table 3.2.7.].

It is evident, then, that Soviet agriculture faces enormous problems. In what follows I will in the main be discussing only one group of problems - those relating to organisation and incentives. Agricultural conditions in the Soviet Union are very difficult, and much of the cultivable area is naturally infertile or prone to drought. All of it, outside Central Asia and
Table 1

Rates of growth of Soviet agricultural output and productivity

(based on figures in value terms)

\begin{tabular}{lrr}
\hline & & $\begin{array}{c}\text { output per } \\
\text { output }\end{array}$ \\
\hline 1966-70 average & 4.0 & 6.7 \\
1971 & 1.1 & 1.8 \\
1972 & -4.6 & -4.2 \\
1973 & 16.1 & 15.6 \\
1974 & -2.7 & -3.1 \\
1975 & -6.3 & -5.4 \\
1976 & 6.5 & 6.5 \\
1977 & 4.0 & 4.4 \\
1978 & 2.7 & 3.1 \\
1979 & -3.1 & -2.4 \\
1980 & -2.5 & -2.0 \\
1981 & -2.0 & \\
\hline
\end{tabular}

Sources: official Soviet and UN statistics

the Caucasus, lies very far north by West European or North American standards. Consideration of comparative advantage might suggest that the Soviet agricultural sector should be sharply reduced in size, and/or radically redirected in terms of the balance of sub-sectors. But the Soviet state has been concerned to maintain a maximum degree of self-sufficiency in foodstuffs, and I do not intend to question this very general strategic orientation. There seems to be broad agreement among Western and Soviet specialists that there is enormous room for improvement in organisation and incentives, whatever other problems exist. There may be less agreement on exactly how best to bring about such an improvement, but relations between the central authorities and the kolkhoz or sovkhoz, and those between the farm and its subdivisions and the farm and the private sector, have been a recurring focus of attention.

\section{The socialist farm}

Kolkhozy have formally always been autonomous cooperatives. Chairmen are formally elected, though in practice always nominated by higher Party or state authorities. Sovkhozy, prior to 1967, were budget financed state enterprises. Now they operate on khozraschot - 'business accounting' - ie they use standard profit-and-loss accounting procedures, and have formally constituted incentive funds, just like any state industrial enterprise. State farms are managed by directors who enjoy, at least in principle, the right of 
edinonachalie - 'one-man-management'. In fact all farms were traditionally subject to a peculiar degree of arbitrary interference from above. Not only did the authorities impose on them obligatory procurement targets, which was in accordance with the planning law of the land, they also tended to tell them how these targets should be achieved, which was strictly illegal. Thus Communist Party 'plenipotentiaries' would descend on a farm, organising campaigns, setting extra targets, often on the basis of little knowledge of local conditions and problems. This was one respect in which the Khrushchev period differed little from the Stalin period, but the 1965 change in government did, at least initially, produce a strong reaction against the tradition. In 1968, a semi-official source declared that 'the plenipotentiary has been abolished' [Yagodin 1968:26]. The number of products carrying a compulsory procurement target for each farm has been reduced, permitting farm managements to take a more positive policy line on specialisation [Gray 1979:546], and the centre has not in recent times sought to determine farm investment patterns systematically [Gregory and Stuart 1981:236]. Certainly the big land improvement schemes of the post1947 period have inevitably interfered in farm operations, and even the movement towards more specialisation has tended to take on the characteristics of an old-style campaign [Gray 1979:546]. But there has been some development in centre-farm relations. The fact that it has failed to make much impression on output trends suggests that the really important organisational variables lie elsewhere.

The counterpoint to all this provided by trends in policy on farm organisation and the private subsidiary sector has been a complex one. As a general rule the authorities have relaxed their attitude on decentralisation at the grass-roots level when things have been very bad, and tightened up when they improved again. Thus the Brezhnev leadership was initially favourably inclined towards intra-farm decentralisation, as they tried to regain the momentum of the early Khrushchev period, but reversed their policy stance in the early 1970s. Now the boot may once again be on the other foot, and private subsidiary agriculture is also currently being much encouraged. Perhaps the best way to evoke this pattern is to look at the history of autonomous organisation within the farm.

\section{The 'link' system}

The principle form of organisation within the kolkhoz and sovkhoz has, throughout the history of postcollectivisation agriculture, been the brigade. A traditional brigade is a largish unit, up to 100 strong, performing general agricultural tasks, and epitomising the extensive utilisation of unskilled labour. The alternative link (zveno), by contrast, is a small unit, often of less than ten people, which is allocated a particular piece of land to work, or a particular specialised function. The link was in favour with Stalin himself in the late 1940s, but fell sharply into disfavour in 1950. In the late 1950s and early 1960s Khrushchev made the link the subject of one of his campaigns - without great success, perhaps because he put the emphasis on the 'crop-attached' link, which has to move from one piece of land to the next with the crop rotation [Pospielovsky 1970:425-6]. The autonomous, or 'normless' link, which came to the forefront in the late 1960 s and early 1970 s, is simply given a small piece of land, (hopefully) the necessary equipment, and left to get on with it. No set tasks as such are handed down, only a sales plan, and members share in the profits of overplan sales [Kolesnevov 1971:23]. The emphasis in this period on the 'land-attached' link represented a clear recognition of the tremendous psychological importance of giving, or rather returning, some real sense of 'mastery' of the land to the peasants [Kopysov 1968:10].

Yet in 1971 I. Khudenko, architect of the highly successful Achki integrated link system, one of the most advanced decentralised forms, was imprisoned on trumped-up charges. He later died in jail [Katsenelinboigen 1978:66]. This by no means spelt the end of the link, or of experiments in decentralisation, but it did represent a reassertion of the power of the Communist Party apparatus men - the rural district Party secretaries etc. They clearly felt that autonomisation was going too far, and they were also worried about the fact that many normless links were in fact being operated by family groups [Ivanov 1968:10]. There was a simultaneous crackdown on the semi-independent operations of rural subsidiary industrial plants, [Dyker 1981:140-2] and it can hardly have been accidental that soon after the 'campaign' approach started to creep back into agricultural policy. For the time being at least, it was going to be the Party and state authorities, not the farms, that decided on patterns of decentralisation.

While links continued to operate on many farms, the late 1970s witnessed a shift in emphasis towards the autonomous brigade. Under this system the brigade council administers, and can modify, the system of incentive payments to members, with direct farmpeasant relationships being reduced to a minimum [Bakhtaryshev 1980:19]. Under full brigade khozraschot (see above), the primary production unit operates, in principle at least, as a quasi-independent minienterprise, with sales, wage-fund and material cost the only planned indicators coming down from farm level [Revenok and Pichugin 1981:19]. The autonomous link, of course, normally does not even have wage- 
fund and cost plans, and the size of the brigade must in any case mean less effective autonomy for the individual peasant than under the link system.

But the trend back to more bureaucracy and more interference over the last ten years has tended to neutralise all these developments. Even where the link system survives and works quite well, for example in large-scale dairy units, it suffers, we are told by a Pravda correspondent, from being over-bureaucratised and too complex, which suggests little effective autonomy for the link. But this writer's answer to the problem is more, not less state and Party interference! [Aksenov 1980:2]. Farm incentive schemes in general are criticised for being so complex and confused that actual payments have in many cases to be made on the basis of 'common sense'. More seriously, the continued prevalence, among planners and within kolkhozy and sovkhozy, of 'ratchet planning' - setting a given year's production or procurement target as a standard percentage mark-up on the previous year's actual production - means that agricultural workers still have a strong incentive to hold back production levels so that next year's plan will not be too demanding. There have indeed, been cases where implementation of the ratchet principle has actually reduced peasants' wages as productivity has risen [Aliev 1980:2]. Clearly no matter how decentralised the particular link or brigade system, positive incentive effects must be damaged if good performance in a given year is effectively penalised in this way. The November 1980 decree on agricultural planning confirms the principle of setting targets on the basis of average actual production levels over a five-year period. Whether agricultural planners, faced with disappointing aggregate results and under pressure from their superiors to 'seek out reserves' among the stronger units, will be able to stick to this self-denying ordinance remains to be seen. Recent reports of payments systems in use in farms using specialised brigades speak of three-year rather than five-year norms, and special rules to stop earnings shooting ahead of productivity [Bogomolov 1982:14].

But whatever general problems exist, the last year or two has once again seen a greater preparedness, at least in some areas, to permit farms to organise their own decentralised systems. In Azerbaidzhan, in the Caucasus, for example, tobacco- and tea-growing, viticulture and potato farming are being increasingly organised on the basis of individual land-attachment. Manuring, irrigation, application of pesticides etc is done on a brigade or farm basis. So-called gektarshchiki - 'hectarers' - are then allotted a hectare and left to organise tending of the crops on a personal basis, perhaps with some help from the family but with no interference from above, except on which crop is to be grown. There appear to be no formal norms as such. Gektarshchiki are simply paid a uniform price per kilogram. however much they turn in, and annual earnings of as much as 3,500 rubles are reported - at least double the average agricultural wage. But by no means everyone is happy with the gektarshchik system. The Azerbaidzhan Agricultural Research Institute, for example, sees it as excessively individualistic, and a hindrance to mechanisation [Agaev 1981:10]. Once again, however, a deepening general crisis in Soviet agriculture seems to be leading to greater policy flexibility on the organisation of the farm. Interestingly enough, subsidiary industrial activity - building, building materials and foodprocessing activities autonomously organised by farms - also seems now to be creeping back into favour [Mikheev 1982:16].

\section{The private sector}

The policy of the Brezhnev leadership towards the private sector of agriculture has been more stable than it was under Khrushchev. Here too, however, there has been a new emphasis on the importance of the sector in recent years, with guidelines being laid down by the July 1978 Plenum of the Central Committee of the CPSU. We can perhaps perceive two main thrusts in the approach to private subsidiary agriculture adopted since the late 1970s. On the one hand, the private sector should, where possible, be integrated into the operations of the socialist sector. On the other hand, where unbridled free enterprise seems the best way, it should be allowed to flourish.

The most straightforward 'deals' that state and collective farms can do with their peasants in their private capacity involves farming out livestock - pigs and cat tle - to the peasants to fatten on their plots. In return for guaranteed supplies of fodder at reduced prices the peasants deliver a proportion of the resultant fatstock to the farm. A problem in the past has been that the peasants have not been allowed to sell their 'share' directly to the farm, but have had to take it to the local agriculture procurement centre. As well as inhibiting the development of cooperation this has let in speculators who go around farms offering high prices [Gomanov 1981:3]. But in Georgia a system has been in operation since 1977 whereby cooperating peasants can sell their private produce directly to the farm, though in this case peasants do undertake formal plans for sales to the farm [Veselov 1979:19]. In Abasha, in Georgia, collective farmers are allowed to keep 10 per cent of the maize harvest on plan fulfilment, and 70 per cent of overplan production. In addition the collective farms are (strictly illegally) giving kolkhozniki an extra hectare of land for private cultivation of maize - on the basis that they keep 70 per cent and give the farm 30 per cent 
of the output, and also agree to sell to the state $200 \mathrm{~kg}$ of meat per annum [Radio Svoboda 1982:2]. Positive reports on this kind of arrangement usually seem to come from the South. In the northern non-Black Earth region problems with fodder supply, and the unwillingness of the younger generation of rural inhabitants to get involved in time-consuming - if idyllic - operations like hay-making, have been among the reasons why the number of livestock in the private sector has fallen sharply in recent years [Sokolov 1982:19]. But there is clearly a desire to try to do something about this.

Where the authorities appear currently to be more prepared simply to give private activity its head is in agriculture outside the state and collective farms. An important part of this is the allotment sector. Town $\mathrm{d}$ wellers are now being encouraged to work small plots of $0.05-0.1$ of a hectare, and permitted to sell their surplus production without any interference whatsoever - ten years ago this sort of thing would get you branded as a parasite and speculator [Rumer 1981]. Even Donbass coal-miners are being encouraged to keep pigs [Monogarov 1980:3]. On a slightly grander scale, enterprises are increasingly developing subsidiary agricultural production on a socialist basis, especially where waste heat etc can be utilised [Rumer 1981]. The Ministry for Light Industry is even issuing formal plan targets for such developments [Rumer 1981:568].

Yet none of this appears to have done anything significant to counteract the negative aggregate trends in Soviet agriculture. Given the unsettled character of government policy, this is perhaps not altogether surprising. Lack of clear long-term prospects must induce quick profit-taking in the private sector and a degree of indifference in the socialist sector. There have, however, been more material problems.

\section{The problem of supply}

The figures cited earlier on aggregate investment in Soviet agriculture are in some ways rather misleading. Much of the money is spent on dubious and/or poorly implemented land improvement schemes. Irrigation projects have frequently resulted in flooding problems and secondary soil salination [Kalmykov and Filipenko 1966]. Supply of key items to farms, on the other hand, has often been unsatisfactory, and this has particularly affected the private plots and links etc. Small mowing machines suitable for cutting hay on wooded and uneven land are not available to the private sector, and neither are mini-tractors, though they were promised a long time ago [Sokolov 1982]. Similar problems have affected the work of the hectarers [Agaev 1981]. The situation was summed up vividly in a letter to Pravda from a frustrated agricultural engineer: 'My working day starts at six in the morning. I check on the work of the mechanisers in the tractor brigades and get the orders for spare parts. Immediately I go off to the raisel'khoztekhnika (district agricultural machinery centre), where I spend the whole day 'winkling out' the necessary components ... For what, I ask myself, did I spend five years in an institute of higher education? To become an "expediter"? Well you don't need higher education for that' [Shirobokov 1980:2].

Perhaps the most insidious effect of all this is to drive supply-hungry farms and farmers into the hands of the pushers and speculators, as notoriously happened with subsidiary industrial production in the early 1970s [Dyker 1981:141-2]. This in turn provokes conservative political reaction which is readier to punish irregularities than to do something fundamental about supply problems. In a recent interview the Minister for Agricultural Machine Building promised an all-round improvement in supply, but made no specific mention of the special supply problems of the lower rungs of the agricultural ladder [Ekonomicheskaya Gazeta 1982:2].

\section{Conclusions}

At the most general level the experience of collectivised agriculture in the Soviet Union must stand, above all, as a stark warning of the dangers of an unbalanced growth strategy which gives priority to collection rather than to collective work. (The phrase was coined by Jerzy Karcz [1968:124].)

Perhaps things might have been different had the period of 'paying tribute' been only five to ten years, but one cannot but be struck by the depth and permanence of much of the socio-psychological damage that was done to the Soviet countryside in the 1930s. Fifty years on, the average kolkhoznik is still ambivalent towards, even disaffected from, the collective farm, though the figures cited on production and investment trends suggest that there is now a powerful 'pumping-over' impetus in favour of agriculture. The demographic damage in terms of age and sex distribution done to the village as succeeding generations of young men were creamed off for the industrialisation drive would have happened anyway, particularly with the intervention of World War II, but the sheer contempt for rural life which the government priorities of the 1930s and 1940s induced has made it much more difficult to recover from that damage. To this day the great majority of rural school leavers want nothing better than to get a town job [Yermishin 1970:4; Chitalov et al 1980:3]. 
More specifically, the experience of the Brezhnev period has shown that much improved average levels of remuneration, reflecting generous price policies, do not by themselves lay a basis for a sustained upward trend in agricultural output and productivity. High levels of investment could surely have been a much more effective lever had the allocation of that investment been rather different. But investment patterns have reflected a preference for grand projects and transformatory strategies which in turn reflect a complex of attitudes that seem to have changed only a little since the Stalin and Khrushchev periods. When the authorities are looking for a way out of immediate difficulties they have shown themselves to be eminently pragmatic about the private sector, and about autonomous organisation within state and collective farms. But when it comes to trying to shift agriculture up a gear the strategy seems to be to involve the peasants as little as possible. Contemporary agricultural planners might be embarrassed by Gor'kii's dictum that Soviet Russia's best hope was that 'the half-savage, stupid and dull people of the Russian villages and countryside will die out' [Gor'kii 1922:43]. But policies have only stuttered in the direction of giving these dull people, if dull they are, an opportunity to renew themselves through participation in decision-taking, be it at ever so humble a level. A package of measures which might form the basis for a recommencement of growth and development in Soviet agriculture would have to include:

- some kind of 'constitution' for the countryside which would spell out the rights of kolkhozy and sovkhozy to reorganise internally, and the rights of the peasant in his/her private capacity, in more or or less 'immutable' form;

- a shift in the allocation of agricultural investment away from grand schemes towards balanced supply of equipment to farms, brigades, links etc;

- a sharp improvement in the efficiency with which land improvement schemes are implemented.

The second measure would be a wrench, but the third might be very difficult outside the context of a significant degree of general decentralisation in the Soviet economic system. The first recommendation comes up against the tradition of arbitrary command which has fired the Bolshevik imagination and permeated Soviet economic administration. There can be no doubt that agricultural reform will be one of the items highest on the agenda of the post-Brezhnev government.

\section{Postscript}

The Food Programme for the period up to 1990 has just been published [Ekonomicheskaya Gazeta, no 22, 1982]. Agricultural prices are to be raised from January 1983, and 10 milliard rubles worth of outstanding kolkhoz debts are to be written off, to free kolkhoz funds for new investment. The private sector and the subsidiary industrial sector are again mentioned as growth points. Much stress is laid on the need for personal initiative, and responsibility, and for an end to 'petty tutelage'.

\section{References}

Agaev, E., 1981, 'Personal'nyi gektar', Literaturnaya Gazeta, 18 March. (I am indebted to A. Kroncher of Radio Liberty, Munich, for this reference.)

Aksenov, K., 1980, 'Dat' prostor novomu', Pravda, 26 October

Aliev, N., 1980, 'Proigryvaet . . peredovik', Pravda, 20 September

Bakhtaryshev, Sh., 1980, 'Organizatsiya i oplata truda zhivotnovodov', Ekonomicheskaya Gazeta, no 43

Bogomolov, F., 1982, 'I stala niva shchedree', Ekonomicheskaya Gazeta, no 8

Chitalov, A., et al, 1980, 'Zemlya zhdet molodykh', Pravda, 21 November

Dyker, D. A., 1976, The Soviet Economy, Crosby Lockwood Staples, London

- 1981, 'Decentralisation and the command principle some lessons from Soviet experience', Journal of Comparative Economics, vol 5 no 2, June

- forthcoming, The Process of Investment in the Soviet Union, Cambridge University Press

Ekonomicheskaya Gazeta, 1982, no 19, 'Sel'skomu khozyaistvu - effektivnye mashiny'

Ellman, M., 1979, Socialist Planning, Cambridge University Press

Gomanov, V., 1981, ‘Kolkhozu podspor'e’, Pravda, 29 April

Gor'kii, M., 1922, O Russkom Krest'yanstve, Izdatel'stvo I. P. Ladyzhnikova, Berlin

Gray, K. R., 1979, 'Soviet agricultural specialisation and efficiency', Soviet Studies, vol 31 no 4, October

Gregory, P. R., and R. C. Stuart, 1981, Soviet Economic Structure and Performance, second edition, Harper and Row, New York

Hanson, P., 1968, The Consumer Sector in the Soviet Economy, Northwestern University Press, Evanston, Illinois 
Ivanov, L., 1968, 'Na tekh li dorogakh ishchem?', Literalurnaya Gazeta, 25 September

Kalmykov, G., and V. Filipenko, 1966, 'Zolotoe dno', Don, no 10; see also Newsletter for Research on Soviet and East European Agriculture, vol 2 no 1, March, 1980

Karcz, Jerzy, 1968, 'Soviet agriculture: a balance sheet', in V. Treml, (ed), The Development of the Soviet Economy, Praeger, New York

Katsenelinboigen, A., 1978, Studies in Soviet Economic Planning, M. E. Sharpe, White Plains

Kolesnevov, S. G., 1971, 'Ekonomicheskoe stimulirovanie i opalta truda v sel'skom khozyaistve', in V. F. Mel'nikov (ed), Ekonomika Sotsialisticheskogo Sel'skogo Khozyaistva v Sovremennykh Usloviyakh, Ekonomika, Moscow

Kopysov, I., 1968, 'Krest'yanin i zemlya', Literalurnaya Gazela, no 6

Mikheev, V., 1982, 'Nadezhnoe podspor'e v ekonomike', Ekonomicheskaya Gazeta, no 19

Monogarov, E., 1980, 'Fermy u terrikonov', Pravda, 13 November

Ostrovskii, V. P., 1967, Kolkhoznoe Krest'yanstvo SSSR, Saratov University Press

Pospielovsky, D., 1970, 'The "link system" in Soviet agriculture', Soviet Studies, vol 21 no 4, April
Radio Svoboda, 1982, 'Materialy issledovatel'skogo otdela', RS 21/82, 5 February

Revenok, L., and P. Pichugin, 1981, 'Kogda poryadok na zemle', Ekonomicheskal'a Gazeta, no 5

Rumer, B., 1981, 'The "second" agriculture in the USSR', Soviet Studies, vol 33 no 4, October

Schroeder, G. E., and B. S. Severin, 1976, 'Soviet consumption and income policies in perspective', in Soviet Economy in a New Perspective, US Congress, Joint Economic Committee, Washington DC

Shirobokov, S., 1980, 'Inzhener ili ekspeditor', Pravda, 16 June

Sokolov, I., 1982, 'Lichnym khozyaistvam nuzhna pomoshch', Ekonomicheskaya Gazeta, no 10

Stalin, J., 1955, Works, vol 12, Foreign Languages Publishing House, Moscow

United Nations, 1977, Economic Survey of Europe in 1976, New York

-1982, Economic Survey of Europe in 1981, Parl II, New York

Veselov, V., 1979, 'Podsobnoe lichnoe - ne lishnee', Ekonomicheskaya Gazeta, no 2

Yagodin, L., 1968, 'Tovarishchi iz raikoma', Ekonomicheskaya Gazeta, no 44

Yermishin, P., 1970, 'Shkol'nik vybiraet dorogu', Pravda, 5 June 